\title{
Akulam Lake Rehabilitation Planning Strategy
}

\author{
Gayatri Krishnan R .J $\mathbf{J}^{\mathbf{1}}$, Gesno George ${ }^{2}$ \\ ${ }^{1}$ M.Plan (Urban Planning) Student, Dept. of Architecture, TKM College of engineering, Kollam, India \\ ${ }^{2}$ Assistant Professor, Department of Architecture, TKM College of Engineering, Kollam, India
}

\begin{abstract}
Healthy lakes and their shores not only provide us with a number of environmental benefits but they influence our quality of life and they strengthen our economy. Lakes cover an important physical feature of India, other than tourism it acts as drinking water source, venue for commercial activities, historical importance venue for sacred holy activities, power generation, and shelter for migratory birds. Currently, India is losing wetlands at the rate of 2-3\% each year. Due to indiscriminate meddling of man, lakes are on the verge of extinction. There is an urgent need to alert world nations about the current state and trajectory of the world's lakes. They are important ecosystems that, when respected and cared for, can sustain a healthy balance of aquatic life, provide us with much enjoyment, and help support our socio-economic needs. The study mainly focuses on the causes of Akkulam lake (a small inland brackish water lake in the southwest coast of Kerala) degradation and importance of lake rejuvenation in tourism sector. And finally planning strategies for the Akkulam lake are formulated based on the rejuvenating efforts through case studies from International and National contexts.
\end{abstract}

Keywords: Wetland, Degradation, Rejuvenation, Planning strategies

\section{Introduction}

Lakes add to the scenic beauty of a landscape. A lake is defined as an accumulation of water in a depression or a basin. They also assist in maintaining a steady flow of water during dry season by releasing the water stored in them to towns and cities situated downstream. The rainwater that could be harvested through these lakes would meet any city's water requirements partially. Initially lakes served as the only source of drinking water for the town or settlement. They are centres of recreation, attracting tourists from far and near. The biodiversity of lakes makes them important as natural resources for tourism. Lakes contribute significantly to socio economic development of the surrounding region.

Harmful activities of man have resulted in degradation of lakes. Environmental degradation often results in a loss of ecosystem services that support human societies. Degradation is mainly due to the lack of public awareness and governmental indifference. The threats and their consequences on lake ecosystems with possible mitigation and restoration measures must be reviewed. Failure to restore or conserve these aquatic ecosystems promptly will result in sharply increased environmental costs and the damage can be irreversible. Achieving better management of these resources requires not only a thorough understanding of the functioning of the ecosystems, but also sufficient planning, financial resources, and community participation. So studies regarding improving the tourism potentiality of lakes without affecting the environment should be done.

\section{Aim of the study}

To study the significance of rejuvenation of lakes and to evolve best planning strategies to enhance Lake Tourism.

\section{Objectives of the study}

a) To study importance of lake forms in tourism sector. b) To study the causes of degradation of lake, opportunities and benefits of lake rejuvenation.

c) To analyse the major issues in and around Akkulam lake.

d) To analyze based on certain parameters like strategies, practices from the case studies taken.

e) To arrive at best planning strategies to rejuvenate Akkulam lake to improve tourism potential.

\section{Ecosystem services of lake}

Ecosystem services as defined by the Millennium Ecosystem Assessment (2003) are: the benefits people obtain from ecosystems. These services are often critical for life and enhance human well-being. As such they are part of the global commons and are often considered to be free. An ecosystem services perspective is an explicit acknowledgement that nature has value and that the value can be measured and used to support environmental management decisions. Every lake can provide a multitude of ecosystem service benefits simultaneously but the actual output of each will depend on the physical characteristics of the basin and the quantity, quality, and timing of water flow. As anthropogenic influences increase ecosystem services and benefits will be affected. This can present significant challenges to managers interested in maintaining multiple ecosystem service benefits while ensuring overall lake health is maintained. 


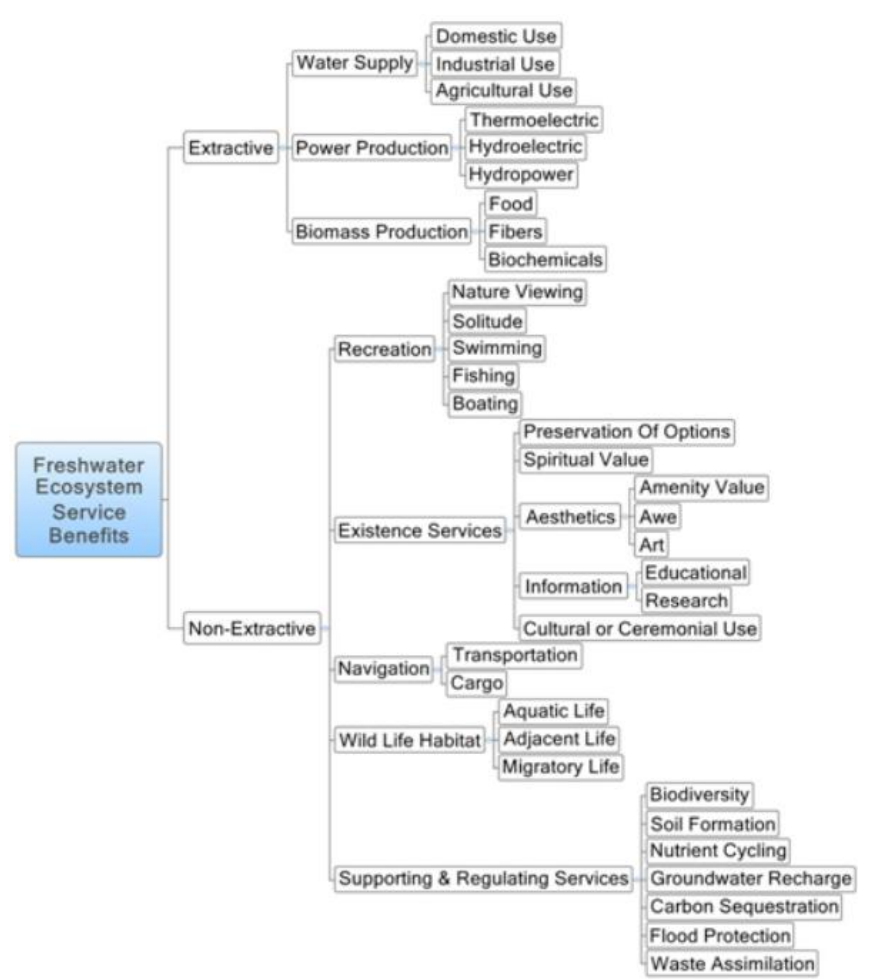

Figure 1: Ecosystem services

\section{Lake degradation and its causes}

Due to indiscriminate meddling of man, lakes are on the verge of extinction. Harmful activities of man have resulted in degradation of lakes. Agricultural wastes, sewage and drainage water from urban areas, absence of wetlands and riparian vegetation near the lakes, etc., are some of the causes that lead to degradation of lakes. Sometimes recreational activities of man also lead to degradation.

Eutrophication, Climate change, Invasion of exotic species, Unplanned tourism development

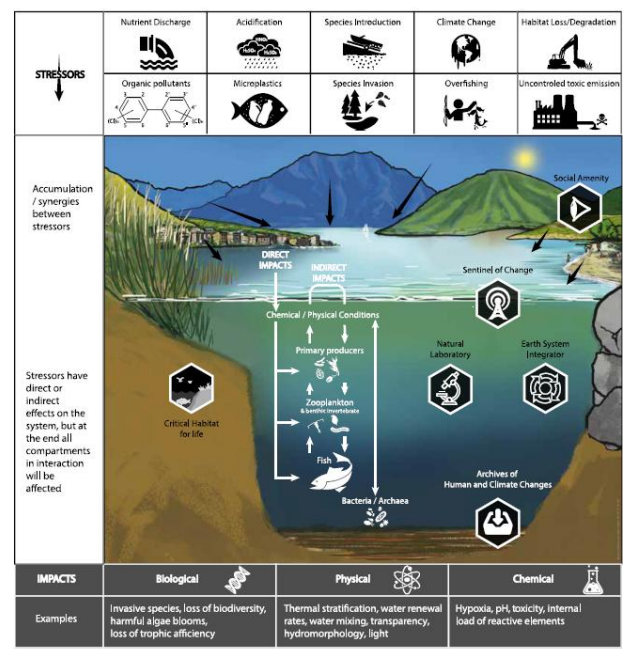

Figure 2: Overview of impacts of stressors.

\section{Lake rejuvenation $\&$ its benefits}

Lake rejuvenation is an effort aimed at restoring the poor health of overexploited and polluted lake bodies. It requires understanding the causes for poor health \& restoration works from source to sink.

- Water management: Maintain optimum water level in the lakes, Eliminate pollution by treating the wastewater inflow, Restore the hydraulic structures

- Urban Space making: Creation of active and vibrant neighborhoods with recreation facilities that is environmentally sustainable, Revitalization of the lakes and to add aesthetic value to the city.

- With regard to Environment \& Biodiversity: Enriching the endemic organisms to improve the lake biodiversity thereby restoring the lake ecosystem.

\subsection{Benefits}

Improvement in the flood management of the watershed, increase the biodiversity of the lake, increase in pisciculture activities, employment generation by eco-tourism activity, increase in recreational facilities and water sports, improvement in the groundwater, improvement in the lake water quality, moderates the climate of surroundings, improvement in human health of lake surroundings, improved aesthetics, enhancement of property values in the lake surroundings.

\section{Study area}

The study area is located in northwest of Thiruvananthapuram district $\left(08^{\circ} 30^{\prime}-08^{\circ} 31^{\prime} \mathrm{N}\right.$ and $76^{\circ} 52^{\prime}-$ $\left.76^{\circ} 53^{\prime} \mathrm{E}\right)$, Veli- Akkulam is a small inland brackish water lake in the southwest coast of Kerala $(1 \mathrm{~km}$ long and $0.3 \mathrm{~km}$ broad). Akkulam Lake is part of the main Akkulam-Veli water body, which is connected to the sea at Veli end by an estuary. The main bridge at Akkulam on the Kazhakoottam Kovalam bypass road divides it into the Akkulam Lake and the Veil lake. With a total water spread area of around $\mathbf{2 2 5}$ acres, the lake is a major place in the urban city limits and is well- connected by roads. The three main storm water drains draining into the Akkulam -Veli Lake are Amazhinjandaan stream, Thettiyar stream and Medical college stream. The Amayizhandaan stream is fed by Ulloor thodu, Pattom thodu and the Pazhavangadi thodu.

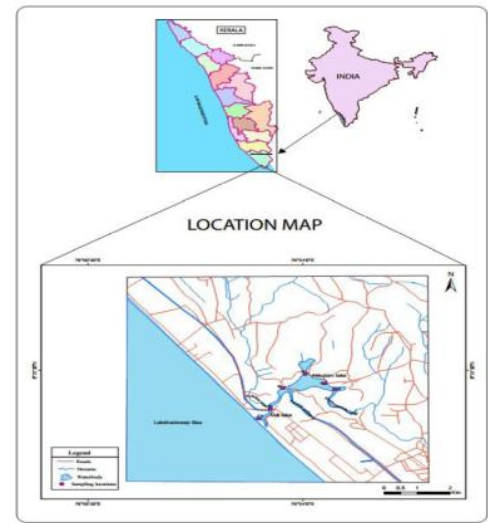

Figure 3: Location of Akkulam lake

7.1 Analysis of existing status 
Akkulam Lake is polluted mainly by untreated sewage reaching the lake. Parvathy Puthanar is part of TS Canal connecting Karamana River and Veli Kayal. Parvathy Puthanar joins Karamana River at Moonnattumukku. This stretch is polluted by discharge of domestic sewage from sewage farm at Muttathara. There are numerous canals in the city which merge with Parvathy Puthanar and Kannammoola thodu. Sewage is also reaching Parvathi Puthanar from individual domestic and commercial establishments on either side through numerous drains. Parvathi Puthanar tows into Veli Kayal while Kannammoola thodu drains into Akkulam lake. Almost all sewage generated in the city reaches Veli-Akkulam Kayal through these streams. All these canals carry untreated sewage which originates from individual households and commercial establishments. They also receive sizeable quantity of sewage from the pumping stations of Kerala Water Authority and from the sewage farm located at Muttathara.

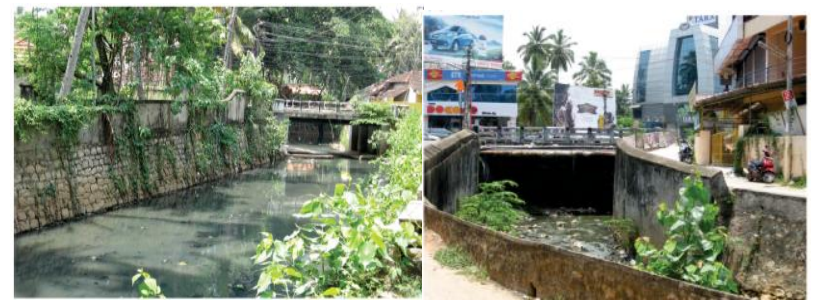

Figure 4: Stream flowing through Kannanmoola \& Plamoodu

The Lake was seriously affected by anthropogenic pressures due to industrial waste discharge, municipal waste disposal, tourism activities, developmental activities, dredging and eutrophication.

Based on various studies conducted on water quality analysis at different samples stations of lakes in Thiruvanthapuram, Akkulam Lake shows high pollution rate. The lake area was 46.37 ha in 2003 and it has shrunk by 40.77ha in 2011and by 39.38 ha in 2019. The parameter BOD in Akkulam Lake varies in the range of 5 to $25.78 \mathrm{mg} / \mathrm{L}$ and in Parvathy Puthanar values shows $12.3 \mathrm{mg} / \mathrm{L}$. This shows that high organic matters are present in the water. The dissolved oxygen (DO) content in Parvathy Puthanar and Amayizhanchan thode is practically 'O' mg/L. In the Akkulam - Veli Lake it varies from 0 to $3.97 \mathrm{mg} / \mathrm{L}$.

Studies on the Akkulam Veli lake floor sediments reveals that the lake is dominated by sand towards the Veli part and clay and silt towards the Akkulam part. The lake has developed multiple environments, each dwelling-specific biodiversity. Moderate $\mathrm{C} / \mathrm{N}$ ratio of the sediments indicates high vegetation growth in the lake and suggests that only minor amount of organic matter from terrestrial sources finds its way in the lake. High amount of $\mathrm{N}$ is being added to the lake through urban sewage that is increasing its eutrophication level. XRD analysis reveals the presence of high amount of Kaolinite mineral towards the Akkulam part suggesting intensive weathering of the surrounding catchment rocks. The diatom analysis reveals diverse species dwelling in the lake, and high population and wide distribution of species such as Cyclotella and Navicula display high organic pollution. This demands careful planning for rejuvenation efforts.

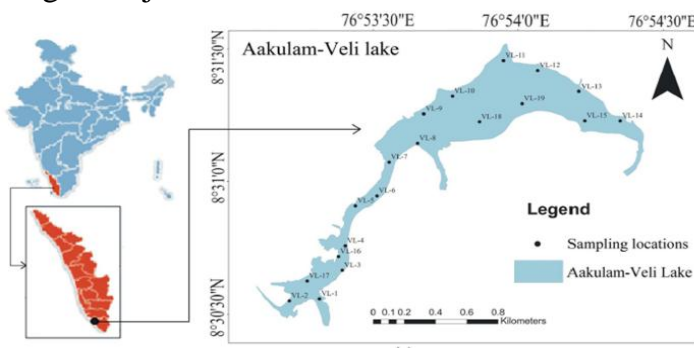

Figure 5: Sampling Location

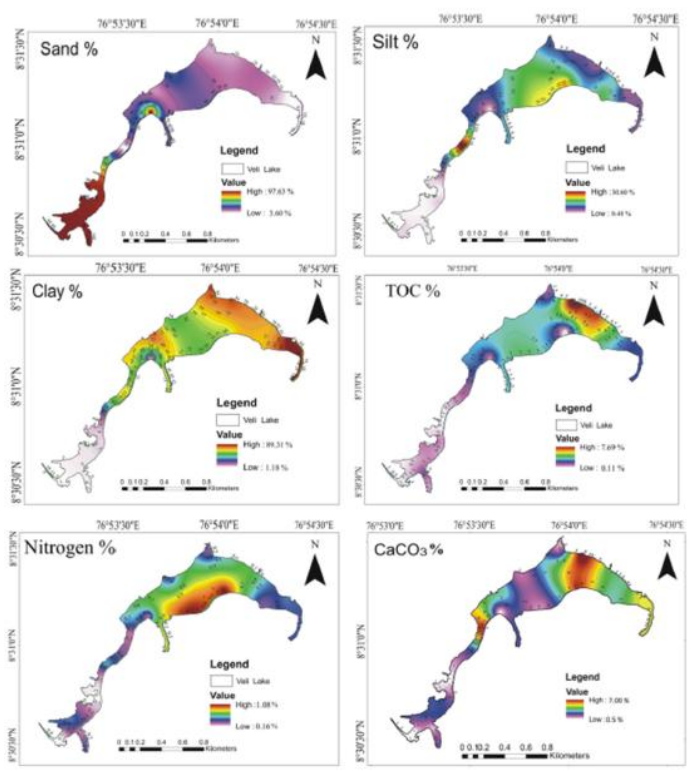

Figure 6: Spatial distribution of sand, silt, clay, toc n, caco3 in akkulam lake and $\mathrm{C} / \mathrm{N}$

From the Spatio-temporal study of land-use/landcover, it is identified that most of the coastal alluvium is gradually being occupied by small- and large-scale buildings. Wetlands have also changed due to reclamation activities. As the years pass, a lot of adverse changes are happening in the land-use and land-cover pattern in and around Akkulam Lake. Agricultural land has been replaced to a large extent by either settlements or industrial establishments. The reclamation activity in the lake area has resulted in the reduction in the original basin capacity.

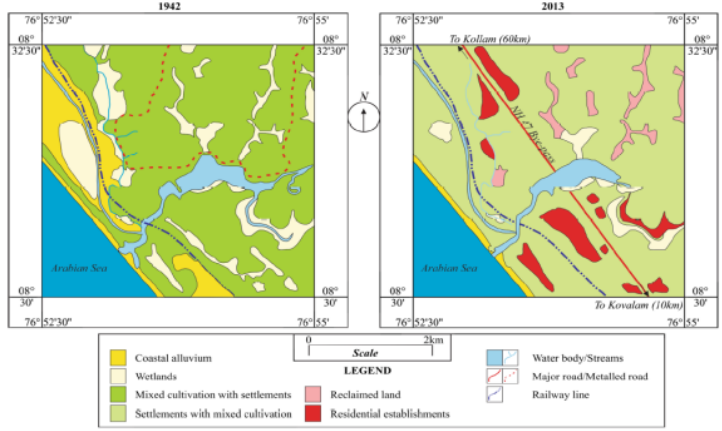

Figure 7: Land-use/land-cover changes in and around Akkulam Lake (1947-2013)

Spatio-temporal study of lake shows that the pressure of the population has resulted in the shrinkage and alteration of this wetland system. 


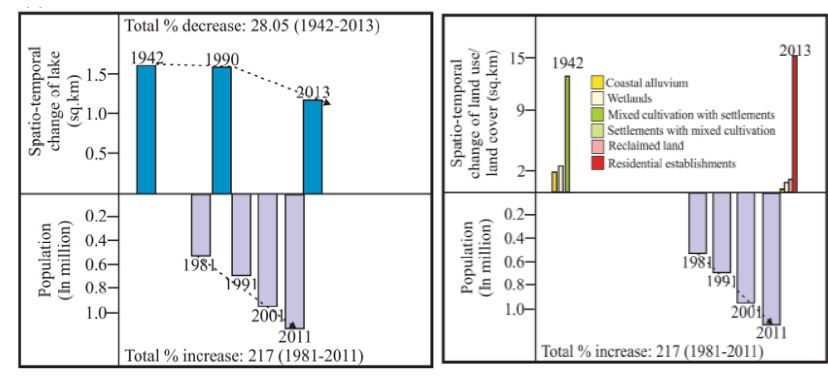

Figure 8: Spatio-temporal change of lake vis-a`-vis increase in population

This once-scenic area has been reduced to a very pathetic condition now with a dense outgrowth of water hyacinth, rusty unused boats parked in the hyacinth-free slots, water body showing a mix of garbage, burnt plastic, wrappers, and all sorts of stinking waste. The lake is almost fully covered with hyacinth. The main reasons for the uncontrolled growth of water hyacinth is that the lake is low in salinity and increased quantity of nutrients supplied by domestic sewage towing into it. With sewage, hospital wastes, etc., being dumped into it, a foul smell taints the air, forcing people to cut short their trip to this picturesque spot.

The Akkulam Tourist Village comprises a boat club, a children's park and a swimming pool. The boat club was formed in 1989. Boats used to ply from the Akkulam Lake all the way to Veli Tourist Village. The lake now is clogged with a dense out-growth of water hyacinth. Unused boats, getting rusty and parked in the hyacinth-free slots, add to the sorry picture.

Recently, the Children's Park and the swimming pool opposite to the Akkulam lake has been renovated. A rejuvenated Akkulam lakefront will add to the value of the place further.

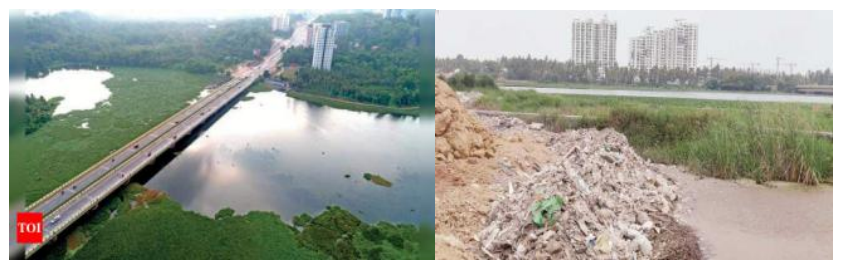

Figure 9: Akkulam lake \& its surroundings

\section{Case studies}

\subsection{Muskegon Lake, Michigan, U S}

The name Muskegon derives from the Ottawa Indian word masguigon, meaning marshy river or swamp. This Michigan City is located along the eastern shoreline of Lake Michigan in Muskegon County. At its northern edge lies Muskegon Lake, a 4,150-acre (1,679-hectare) inland coastal lake.

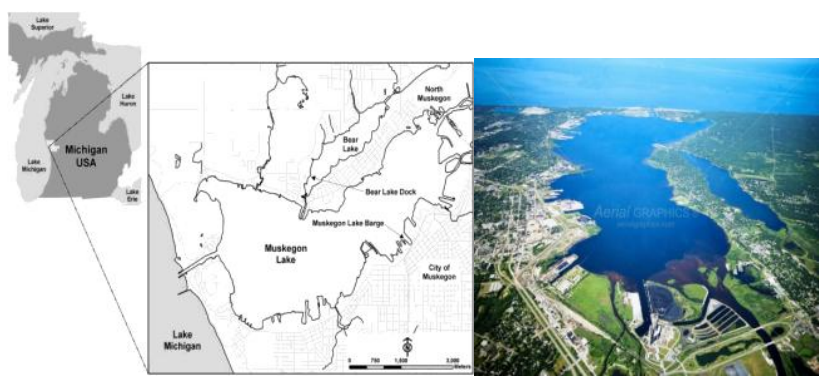

Figure 10: Location of Muskegon Lake, U S

During the lumber era (roughly 1860-1910), Muskegon Lake had 47 saw mills along its shoreline, and Muskegon boasted, at one time, more millionaires per capita than any town in America.

During World War II, Muskegon's Continental Motor Company produced tank, aircraft, and automobile engines as part of the war effort that led to its reputation as a foundry town. Historical development along Muskegon Lake supported waterfront-dependent industry and commerce, leaving behind a legacy of contaminated sediments, habitat loss, and environmental degradation.

\subsubsection{Plan and Implementataion}

Contaminated Sediment Remediation: Contaminated sediment was a long-standing issue in the Muskegon Lake AOC (Area of concern) because of historical industrial activities.

Through the RAP(Remedial Action Plan), and with critical financial support from the Great Lakes Legacy Act (started in 2002) and the GLRI (started in 2010), substantial contaminated sediment remediation has been completed or is underway in the AOC, including remediation of 89,869 cubic yards $(68,710$ cubic meters) of contaminated sediment in Ruddiman Creek in 2006 (\$14.2 million), remediation of 43,463 cubic yards $(33,230$ cubic meters) of contaminated sediment at the Division Street Outfall in 2012 (\$10.8 million), and remediation of 44,000 cubic yards $(33,640$ cubic meters) of contaminated sediment and soil in the vicinity of the Zephyr Oil Refinery that is underway now and projected to be completed in 2019 (\$17 million).

Habitat Restoration and Conservation: Through the RAP, and with critical financial support from the GLRI and the Great Lakes Legacy Act, substantial habitat restoration and conservation work has been completed or is underway in the AOC. Projects include: Lumber mill debris removal and aquatic habitat restoration, Veterans memorial park fish and wildlife habitat restoration, Beer Creek fish wildlife habitat restoration and Lower Muskegon River fish and wildlife habitat restoration were carried out during 2017- 2019 respectively. 

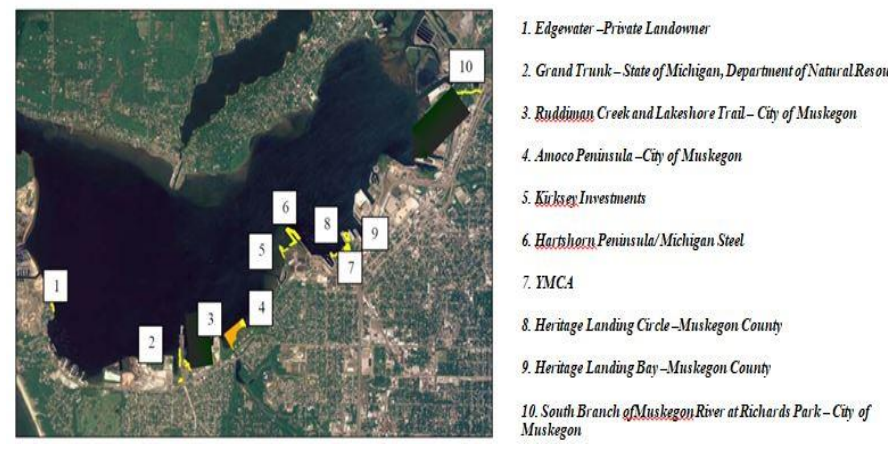

Figure 11: Major sites considered in the Restoration Project

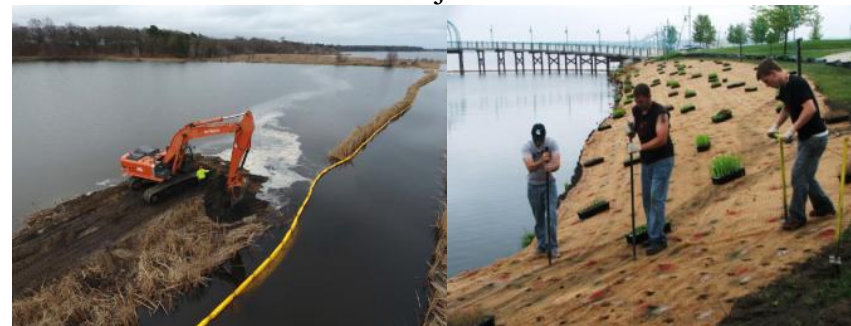

Figure 12: Berm removal Figure 13: Slope stabilization

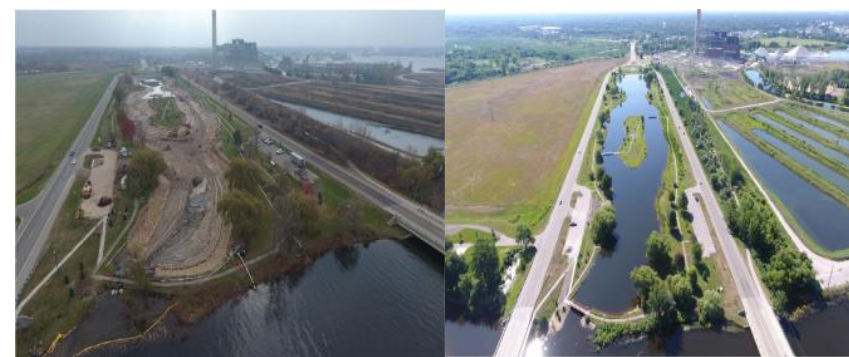

Figure 14: Veterans Memorial Park during and after habitat restoration.

\subsubsection{Achievements}

In 2009, the Great Lakes Commission and the West Michigan Shoreline Regional Development Commission were awarded \$10 million from the American Recovery and Reinvestment Act to remove 24.7 acres (10 hectares) of historical, unnatural fill, restore 27 acres (11 hectares) of wetlands, and soften 1.9 miles (3 kilometers) of shoreline along the south shore of Muskegon Lake. As part of this restoration effort, economic benefits were measured via hedonic property values and a travel cost survey for lakebased recreation.

This socioeconomic study measured the economic value before, during, and after restoration. The hypothesis was that habitat restoration would increase the economic value of ecosystem services associated with restored wetlands, which local governmental and economic development authorities could then use to promote local tourism and commerce. This required a survey of lake users, a survey of possible users of the lake, and housing sales information. These data were then used to quantify the value of recreation, the number of new visitors, and the increase in housing value from the ecosystem improvements.

This study found that the $\$ 10$ million Muskegon Lake restoration project will generate nearly $\$ 60$ million of economic benefits for the Muskegon area over a 20-year period, or a 6-to-1 return on investment. These economic benefits included a $\$ 12$ million increase in property values; up to $\$ 600,000$ in new tax revenue annually; over $\$ 1$ million in new recreational spending annually in Muskegon; and nearly 65,000 additional visitors annually.

\subsection{Jakkur Lake, Bengaluru, India}

Jakkur Lake is one of the largest lakes in the grid of manmade lakes in the city and is located in the north eastern part of Bengaluru. Unplanned development in the area surrounding the lake had led to solid waste filling its feeder channels. This choked the natural watershed so much that the lake resembled a dumping yard.

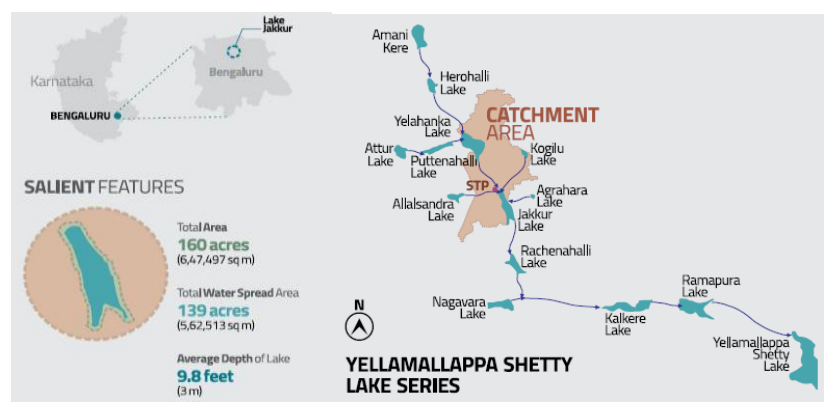

Figure 15: Location of Jakkur lake

Jakkur Lake receives water from the eastern, western and northern side.

a) Eastern Side: The water flows in through Tirumunahalli, Agrahara and then Chobandanahalli and finally enters the Jakkur Lake.

b) Western Side: The water flows in through the Shivanahalli Lake.

c) Northern Side: Water flows in through Attur, Puttenahalli, Allasandra, Yelahanka, Kogilu and then finally into Jakkur.

d) Outlet: The overflow from Jakkur Lake feeds the downstream lake of Rachenahalli and Nagawara Lake.

\subsubsection{Plan and Implemetation}

Multiple organisations have been involved in the journey of restoring this lake. Jakkur Lake was originally under the Lake Development Authority. In 2008, all rejuvenation works were handed over to the Bangalore Development Authority when all the major interventions took place. Moving forward, the custody went to BBMP and currently rests with them. An MoU was signed with Jalposhan Trust to take over the maintenance of the lake. Additionally, the Karnataka State Pollution Control Board (KSPCB) regularly monitors the water quality of the lake. This is supplemented by the Indian Institute of Sciences and Ashoka Trust for Research in Ecology and the Environment who also do the same for research and development purposes. Biome has actively supported the lake rejuvenation work. Fisheries department by way of release of tender for fishing continues to be involved in the overall management of the lake. Forest department is continuously involved as they support Jalposhan Trust by providing them with native plant species and structured removal of invasive species.

a) Preparatory Interventions: Desilting, Dewatering, Construction of bunds and pathways. 
b) Lake recharge \& Wastewater Treatment Interventions: Creation of Constructed Wetland System, Diversion of treated wastewater from Jakkur, STP through Constructed Wetlands into the lake, Construction of Sedimentation Trap.

c) Biodiversity Enhancement Interventions: Vanmahotsav for tree plantation and increasing the interaction of the residents with the lake, Bird Watching and Tree Tagging, Bifurcation of community and conservation zone within the lake premises, Slope stabilization through Vettiver plants.

d) Allied Interventions: Harvesting of plants in the constructed wetland

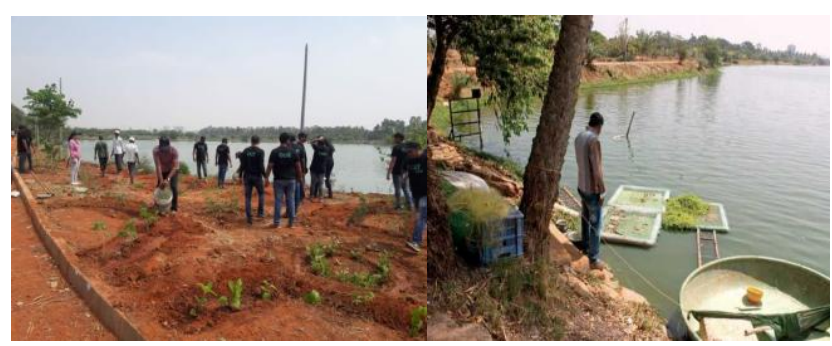

Figure 16 : Rejuvenation works by local residents

Active participation of local residents for improving the conditions of the lake. A consensus was reached between the villagers and BBMP that they would draw the water and use it beyond the lake boundary for their activities. Jal Poshan fulfilled the role of coordinating between all agencies to maintain the lake.

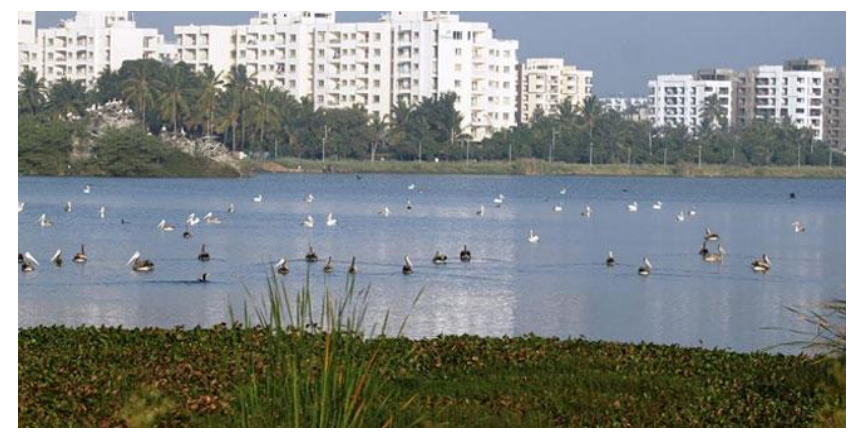

Figure 17: Jakkur lake (after rejuvenation)

\subsubsection{Achievements}

At present the wetlands are performing very well in the removal of organics and nutrients. There is more than $98 \%$ removal of organics and nutrients by the time the water reaches the lake. Jakkur lake restoration project has provided livelihood opportunity to fishermen. On a normal day, they are able to collect at least 100 kilograms of various kinds of fish. 100,000 liters per day of water is drawn from a step well near the lake for agricultural purposes. Improved biodiversity in the surrounding area with increased presence of local and migratory birds. Increased land value of nearby properties.

\section{Strategies}

1) Preparatory interventions(Immediate interventions): a) Awareness generation to the local residents regarding the project through door-to-door campaigning and pamphlet distribution.

b) Formation of committee by including people from all relevant sector( civic bodies, private agencies \& Local representatives).

a) Conduct Reconnaissance survey of the lake initially for the demarcation of project boundary with partial fencing.

b) Promote active participation of local residents for the removal of floating waste and vegetation from lake and accumulated water on the walkway.

c) Prepare the lake area through desilting and dewatering operations.

2) Lake Recharge \& Wastewater Treatment Interventions (Long term interventions):

a) Remodeling of the natural wetland into an improved wetland through installation of Floating Aerators and treatment through artificial floating wetlands.

b) Construction of permeable bund as a boundary of sedimentation tank.

c) Construction of silt trap and installation of sluice gate.

3) Biodiversity Enhancement Interventions (Long term interventions):

a) Plantation of native plant species inside the lake premises through the local people involvement.

b) Slope stabilization near the banks of lake by planting bamboo and Vettiver grasses through community participation

c) Creation of Artificial bird perching islands within the lake at different locations.

\section{4) Recreational \& Alllied Interventions(Long term} interventions)

a) Creation of tourism oriented infrastructures including Lake Front Promenade, walkway, cycling track and recreational parks.

b) Income generation of local people can be improved through various waterway services.

c) Construction of open -amphitheaters for showcasing various cultural events

d) Installation of attractive waste bins with creative ideas to evoke the cultural spirit of the area as a part of solid waste management.

e) Permanent workforce formation for the Continuous monitoring and maintenance to ensure that the treatment infrastructure is performing its intended purpose.

\section{Conclusion}

The study was an attempt to formulate planning strategies to rejuvenate Akkulam lake to enhance tourism activities. This was done through analysing the planning aspects using the literature study and case studies.

Then how the lake beauty suffers due to the anthropogenic activities and their impacts on lake degradation are studied well through various literature review. This indeed leads to understand the concept lake rejuvenation. Benefits derived 
through lake rejuvenation are studied which helps in improving the tourism.

By analyzing the case studies, how the dying lake could be rejuvenated through various efforts including long term to short term interventions at different places is understood. Parameters identified from literature review helped to analyze the case studies in enhancing tourism activities.

And finally best planning strategies to rejuvenate lake to improve tourism potential are formulated. From the analysis of various case studies the best strategies that could be adopted for the rejuvenation of dying lake is formulated. Besides all the intervention efforts taken by the Government, great awareness should be developed among the people in understanding their responsibility to conserve and maintain the lake premises for future generations as the lakes play a crucial role in providing them ecosystem services.

\section{References}

[1] Michigan Department of Environmental Quality. (2011). Retrieved from Stage 2 Remedial Action Plan: Muskegon Lake Area of Concern. Lansing, Michigan, USA.

[2] Anderson, S.T., J. Read, and D. Scavia. ( 2009). Restoring Great Lakes ecosystems: Worth the cost? University of Michigan, Graham Sustainability Institute, Ann Arbor, Michigan, USA.

[3] Consortium for DEWATS Dissemination (CDD) Society, Bengaluru. (December, 2019). Waterbody Rejuvenation - A Compendium of Case Studies.

[4] Daubariene, J. (N.D.). The Influence of Lakes on the Tourism. Sociālo zinātņu žurnāls, 2, 77-86.

[5] Helen Bennion, Gavion L. Simpson, Ben J. Goldsmith. (n.d.). Assessing degradation and recovery pathways in lakes impacted by eutrophication using the sediment record.

[6] Jean-Philippe Jenny, O. A.-M. (2020). Scientists' Warning to Humanity: Rapid degradation of the world's large lakes. Journal of Great Lakes Research, 686-702.

[7] Ramachandra T.V, S. V. (September 2020). Efficacy of rejuvenation of lakes in bengaluru, INDIA. Green Chemistry \& Technology Letters.

[8] Marc schallenberg, m. D. (november 2013). Ecosystem services of lakes. Ecosystem services in new zealandconditions and trends

[9] Ranjana Siva, T. K. (March 2019). Rejuvenation of Lakes in Indian Cities: A Case Study for the Betterment of Wetlands in Bangalore.

[10] Partnership, Muskegon Lake Watershed. (2018). Muskegon Lake Ecosystem Action Plan. Muskegon, Michigan, USA. 